University of Nebraska - Lincoln

DigitalCommons@University of Nebraska - Lincoln

U.S. Environmental Protection Agency Papers

U.S. Environmental Protection Agency

Fall 2004

\title{
Using Wind To Power a Groundwater Circulation Well-Preliminary Results
}

\author{
Andrew Curtis Elmore \\ University of Missouri-Rolla \\ Ron Gallagher \\ University of Missouri-Rolla \\ K. David Drake \\ U.S. Environmental Protection Agency
}

Follow this and additional works at: https://digitalcommons.unl.edu/usepapapers

Part of the Civil and Environmental Engineering Commons

Elmore, Andrew Curtis; Gallagher, Ron; and Drake, K. David, "Using Wind To Power a Groundwater Circulation Well-Preliminary Results" (2004). U.S. Environmental Protection Agency Papers. 5. https://digitalcommons.unl.edu/usepapapers/5

This Article is brought to you for free and open access by the U.S. Environmental Protection Agency at DigitalCommons@University of Nebraska - Lincoln. It has been accepted for inclusion in U.S. Environmental Protection Agency Papers by an authorized administrator of DigitalCommons@University of Nebraska - Lincoln. 


\section{Using Wind To Power a Groundwater Circulation Well-Preliminary Results}

\section{Andrew Curtis Elmore}

\author{
Ron Gallagher
}

\author{
K. David Drake
}

In areas of the country where the U.S. Department of Energy has classified the available wind resources as Class 3 or greater, the use of wind turbines to provide power to relatively small remediation systems such as groundwater circulation wells may be technically and economically feasible. Groundwater circulation wells are a good candidate technology to couple with renewable energy, because the remediation system removes contamination from the subject aquifer with no net loss of the groundwater resource, while the wind turbine does not create potentially harmful air emissions. Wind data collected in the vicinity of the former Nebraska Ordnance Plant Superfund site were used to select a wind turbine system to provide a portion of the energy necessary to power a groundwater circulation well located in an area of high trichloroethylene groundwater contamination. Because utility power was already installed at the remediation system, a $10 \mathrm{~kW}$ grid inter-tie wind turbine system supplements the utility system without requiring batteries for energy storage. The historical data from the site indicate that the quantity of energy purchased correlates poorly with the quantity of groundwater treated. Preliminary data from the wind turbine system indicate that the wind turbine provides more energy than the remediation system treatment components and the well submersible pump require on a monthly average. The preliminary results indicate that the coupling of wind turbines and groundwater circulation wells may be an attractive alternative in terms of the system operation time, cost savings, and contaminant mass removal. (c) 2004 Wiley Periodicals, Inc.

\section{INTRODUCTION}

The general trend in groundwater remediation is to focus on resource-conservative methods, which treat contamination without reducing the quantity of groundwater available for use. Resource conservative technologies include:

- permeable reactive barriers (PRBs), which treat groundwater in situ, using zerovalent iron or other treatment media;

- biologically active zone enhancement, which involves the periodic introduction of an electron donor substance or other amendment to stimulate bacterial activity in the subject aquifer;

- phytoremediation, which relies on plant uptake and biotreatment of relatively shallow groundwater;

- monitored natural attenuation, which does not require supplemental treatment;

- some pump-and-treat systems, which involve the reinjection or recharge of treated groundwater to the subject aquifer; and

- other systems that do not significantly modify the preremediation water balance. 
The use of pump-andtreat systems with reinjection options may address some of the challenges associated with the in situ systems.
One of the major challenges associated with the in situ PRB and biodegradation technologies is that significant monitoring of intermediate and final degradation products is required to manage any increase in human health-risk levels associated with the generation of toxic daughter products. Another challenge is that the effectiveness of these technologies requires a good understanding of the groundwater flow regime so that the treatment materials may be placed in the appropriate locations. These challenges are often outweighed by the typically low operation and maintenance $(\mathrm{O} \& M)$ costs of the technologies. For example, a well-designed and constructed PRB may not require any maintenance outside of routine groundwater monitoring for several years after construction. However, accessibility may hamper the implementation of PRBs at some sites. Unlike active systems, such as pump-andtreat, which can be "offset" to accommodate land use and still be effective to some degree, PRBs require relatively precise placement.

The use of pump-and-treat systems with reinjection options may address some of the challenges associated with the in situ systems. For example, the treatment component of such a system may be engineered to effectively treat contamination without the generation of any toxic byproducts in the treated water. Furthermore, the design of pump-and-treat systems may be somewhat more robust relative to PRBs and other in situ systems, because the contaminated water is actively moved to the extraction well through pumping. However, the operation costs of pump-and-treat systems may be significant due to both costs directly related to treatment and the cost of conveying groundwater from the aquifer to the treatment unit, from the treatment unit to the reinjection location, and back into the aquifer. The Underground Injection Control (UIC) regulations may require that the groundwater undergo treatment for the project contaminants of concern and any other unacceptable chemicals prior to reinjection. Additionally, wells require periodic maintenance and eventual replacement in order to maintain design production levels.

The combination of a groundwater circulation well $(\mathrm{GCW})$ with a renewable energy source may present a combination of benefits that will be attractive at sites where:

- the aquifer will support a GCW system and

- sufficient renewable energy resources are available.

The GCW/wind turbine system may be especially attractive at sites where the cost of installing and/or the purchasing of utility power are high.

A GCW is a quasi-in situ treatment technology that uses a single well with hydraulic isolated multiple-screened sections to extract and recharge groundwater. The systems include a component to treat the groundwater prior to recharge. A GCW variant includes the use of pairs of multiple screen wells to set up horizontal circulation wells instead of the vertical circulation cells associated with single GCW systems. Typically, the systems are exempt from UIC regulation, or a UIC waiver may be obtained, because the intent of the system is to improve the groundwater quality at the GCW location. The treatment component may be designed for virtually any contaminant, while PRBs and biodegradation systems may be limited to specific contaminants. For example, Elmore and Graff (2002) describe the application of best-available technology design applied to a GCW located in an area of trichloroethylene (TCE) contamination and a GCW system located in an area of contamination by the explosive compound hexhydro-1,3,5-trinitro- 
1,3,5-triazine, known as RDX. Groundwater monitoring and modeling may also be used to characterize the area of the aquifer treated by a GCW as described in Elmore and DeAngelis (2004) and Elmore and Hellman (2001).

The operation and maintenance costs for a GCW should be lower compared to a comparable pump-and-treat system with remote reinjection simply because energy is not required to transfer groundwater from the extraction wells to the treatment facilities to the recharge wells. GCWs still require periodic well rehabilitation, as with any well, and the overall O\&M cost of a GCW system should be expected to be higher relative to a well-designed and -constructed PRB system. However, the use of a renewable energy source has the potential to significantly reduce the annual O\&M cost of a GCW system while potentially reducing air emissions associated with the generation of fossil fuel-based power. Gipe (1995) summarizes emissions offset associated with the use of renewable energy in the place of fossil fuel energy. That summary gives a range of average emissions for power generation in the United States as 0.07 to $4 \mathrm{~g} / \mathrm{kWh}$ of nitrogen oxides and 487 to $940 \mathrm{~g} / \mathrm{kWh}$ for carbon dioxide.

\section{PROJECT BACKGROUND}

The former Nebraska Ordnance Plant (NOP) occupied more than 17,000 acres in east-central Nebraska near the village of Mead in Saunders County. The facility produced ordnance from 1942 to 1956 during World War II and the Korean Conflict. The plant was used for munitions storage and ammonium nitrate production. The prevalent explosive compound released into the environment is RDX. In 1959 and 1964, the facility was used to construct and maintain Atlas missiles. TCE was used as a degreaser during the missile construction. Spent TCE was released to the ground and entered the unconfined groundwater aquifer, which is used regionally for water supply. The former NOP site was included on the National Priorities List under the Comprehensive Environmental Response, Compensation, and Liability Act (CERCLA, or Superfund) on August 30, 1990. Since then, investigations have identified two RDX groundwater contamination plumes and two TCE plumes (United States Environmental Protection Agency [US EPA], 1990). In April 1997, a pump-and-treat groundwater remedy was selected for the site. Currently, 11 groundwater extraction wells have been constructed along the leading edge of the plumes. The purpose of these wells is to use hydraulic containment to prevent contamination from migrating to uncontaminated areas. The combined design flow from these wells is 2,650 gallons per minute (gpm). The groundwater Record of Decision included focused remediation with the hydraulic containment to balance the objective of decreasing remediation time with the needs of the local community to use groundwater for agricultural irrigation, domestic, and other uses. The community interest in groundwater conservation, as described by Elmore and Graff (2001), led to the pilot-testing of two GCW systems, beginning in May 2000.

One of the pilot GCWs, known as GCW-1, was installed in an area where there were TCE concentrations in the groundwater on the order of 5,000 $\mu \mathrm{g} / \mathrm{L}$ or greater and there are no other contaminants present. The former NOP site cleanup goal for TCE is $5 \mu \mathrm{g} / \mathrm{L}$. The GCW-1 pilot study results are described in Elmore and Graff (2002). GCW-1 was left in service after the completion of the pilot study, and it currently remains in service.
The operation and maintenance costs for a GCW should be lower compared to a comparable pumpand-treat system with remote reinjection. . . 


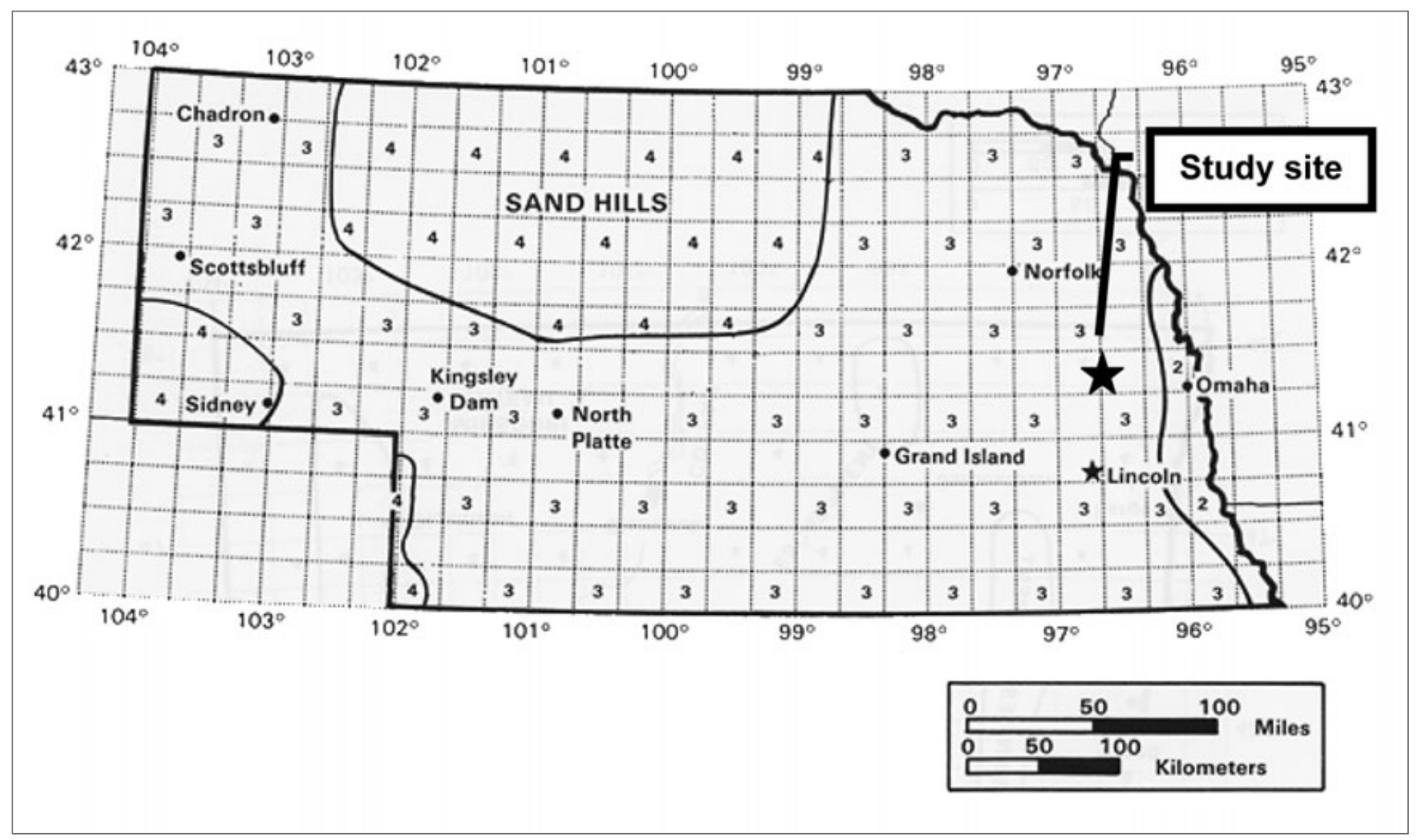

Exhibit 1. Nebraska average annual wind power classes (after Elliott et al., 1986)

\section{SYSTEM DESIGN AND CONSTRUCTION}

In 2003, work was initiated to demonstrate the use of wind power using GCW-1 at the former NOP site. Specific project objectives include:

- characterization of the reduction in the consumption of utility power by comparing the quantity of wind power consumed during the demonstration to the historical energy consumption and

- characterization of the mass quantity of TCE removed from groundwater during the demonstration period.

The University of Missouri-Rolla (UMR) Geological Engineering Capstone Design class performed the system design during the fall 2003 semester.

The U.S. Department of Energy (DOE) categorizes wind resources using wind power classes ranging from Class 1 to Class 7 (Elliott et al., 1986). Each class represents a range of mean wind power density (in units of $\mathrm{W} / \mathrm{m}^{2}$ ) or equivalent mean wind speed at a specified height(s) above ground. Areas designated Class 3 or greater are suitable for most wind turbine applications, whereas Class 2 areas are deemed marginal by Elliott et. al. (1986). The study site location shown in Exhibit 1 was classified as a Class 3 area by Elliott et al. (1986). The Class 3 wind power density range is 150 to $200 \mathrm{~W} / \mathrm{m}^{2}$ at a height of $10 \mathrm{~m}$, and the range of mean wind speeds is 5.1 to 
$5.6 \mathrm{~m} / \mathrm{s}$ (or 11.5 to $12.5 \mathrm{mph}$ ). The Class 3 wind power designation for the study site indicated that the site was an appropriate candidate for a wind turbine installation. In fact, the Lincoln (Nebraska) Electric System operates two $750 \mathrm{~kW}$ wind turbines approximately 30 miles from the study site as a part of the utility's Renewable Energy Program.

The GCW system consists of the following primary electrical machinery:

- a $1.5 \mathrm{hp}$ submersible well pump used to extract water from the aquifer to the air stripper;

- a $5 \mathrm{hp}$ blower used to circulate air through the stripper; and

- a 1 hp centrifugal pump used to return treated water from the stripper sump to the well.

Additional equipment includes an electrical control panel and small chemical feed pump to add a buffering agent to the groundwater after treatment. The electrical loads created by this equipment are assumed to be negligible relative to the equipment listed above, which has an aggregate power rating of $7.5 \mathrm{hp}$ or $5.6 \mathrm{~kW}$. In addition to the treatment-related electrical equipment, GCW-1 includes additional equipment for climate control. The original purpose of GCW-1 was to serve as a pilot system to generate data to be used for the design of additional systems at the site. The pilot system included a thermostat-controlled ventilation fan to provide cooling of the building that housed the air stripper blower, the control panel, and the chemical feed system. An electric radiant heater was subsequently added to the vault containing the air stripper and the centrifugal pump, and a second heater was installed in the GCW-1 building.

The GCW was designed to operate continuously, and neglecting the heating and cooling energy demands, the maximum monthly demand for the treatment system was estimated to be the product of $6 \mathrm{~kW}(7 \mathrm{hp})$ and $720 \mathrm{hr} /$ month, or approximately 4,000 $\mathrm{kWh} /$ month. This estimate does not include any energy costs associated with heating and cooling. During the period of June 2000 through December 2000, a total of 19,032 $\mathrm{kWh}$ of electricity were purchased from the local utility resulting in an average monthly consumption of $2,718 \mathrm{kWh} /$ month. Based on the maximum monthly demand estimated for the treatment system calculated above, the seven-month maximum demand was estimated as 30,000 kWh. Assuming that all other electrical demands are negligible, it was estimated that the system operated approximately 60 percent of the time based on the quantity of electricity consumed. During this same period, 12,120,000 gallons of water were treated by the system. Assuming that the system operated at an average flowrate of $50 \mathrm{gpm}$, the system was in operation approximately 80 percent of the time, based on the quantity of water treated. The GWC-1 flowmeter readings were manually recorded between 48.9 and $50.1 \mathrm{gpm}$ (Elmore \& Graff, 2002); thus, the operation time estimate of 80 percent appears to be reliable. The practice of using motor power ratings and utility power consumption records to estimate operation time appears to be less reliable.

The Nebraska Power Association conducted a four-year study to identify potential locations for wind energy development from 1995 to 1999 as described by Global Energy Concepts, Inc. (GEC; 1999). The study consisted of the monitoring of eight stations across Nebraska including a station at Wahoo, Nebraska, that is approximately 11 miles from the former NOP site. Over the four-year monitoring period associated with
The practice of using motor power ratings and utility power consumption records to estimate operation time appears to be less reliable. 
Seasonal data showed that the highest wind speeds occurred during the fall and winter, with the lowest winds in July and August. the GEC (1999) study, the following data were collected using a $40 \mathrm{~m}$ anemometer at the Wahoo station:

- average wind speed- $6.4 \mathrm{~m} / \mathrm{s}$

- wind shear exponent- 0.27

- turbulence intensity- 0.17 to 0.21

Seasonal data showed that the highest wind speeds occurred during the fall and winter, with the lowest winds in July and August. The diurnal wind pattern indicated that the wind speeds decreased slightly in the early morning and evening hours.

Several wind turbine performance models are available on the Internet, including a spreadsheet model at www.bergey.com/Technical/ExcelS.xls. The models use a modified version of the Weibull probability density function to estimate the probability $f$ that a given wind speed $x$ will occur given the average turbine hub wind speed $u$ and $a$ Weibull shape factor $K$ according to the following equation:

$$
f(x)=\frac{0.89 \cdot k}{u} \cdot\left(\frac{0.89 \cdot x}{u}\right)^{k-1} \exp \left[-\left(\frac{0.89 x}{u}\right)^{k}\right]
$$

The total energy output for a wind turbine is found by calculating discrete probabilities of wind speed across a range of values, such as 1 to $20 \mathrm{~m} / \mathrm{s}$. The product of those probabilities and discrete values from the specific wind turbine power curve are summed to estimate the energy output. The wind shear exponent is used to correct for height differences between the anemometer and the wind turbine. The spreadsheet at the Web site given above was used to estimate the total average annual energy output of a Bergey Windpower Company Excel S 10kW wind turbine using the Wahoo data with the following results:

- $\quad 15,600 \mathrm{kWh}$ for a $30.48 \mathrm{~m}(100 \mathrm{ft})$ tower

- $18,100 \mathrm{kWh}$ for a $40 \mathrm{~m}(130 \mathrm{ft})$ tower

GEC (1999) estimated energy production using the wind speed distribution at the Wahoo monitoring site and the power curve for a $750 \mathrm{~kW}$ wind turbine on a $40 \mathrm{~m}$ tower as 6,134 MWh per year. Assuming that the power curve is proportional according to the wind turbine ratings, the corresponding annual value for a $10 \mathrm{~kW}$ system would be $20,500 \mathrm{kWh}$, which is about 12 percent more than the value estimated above using the modified Weibull model.

Exhibit 2 summarizes the energy supply-and-demand estimates calculated during the system design. A $10 \mathrm{~kW}$ wind turbine would supply approximately 50 percent of the energy needs of the GCW system. Exhibit 2 also provides estimates of the cost savings associated with using the $10 \mathrm{~kW}$ wind turbine system. The wind turbine could be operated in two manners:

- Independent of any other power source - In this configuration, the GCW system would only operate using the energy generated by the wind turbine system. This configuration would probably require intermittent operation of the GCW sys- 


\begin{tabular}{|l|r|r|}
\hline \multicolumn{1}{|c|}{$\begin{array}{c}\text { Estimated Annual Supply from Wind } \\
\text { Turbine }\end{array}$} & $\begin{array}{l}\text { Estimate from } \\
\text { Modified Weibull } \\
\text { Model }\end{array}$ & $\begin{array}{l}\text { Estimate from GEC } \\
\text { (1999) Production } \\
\text { Estimate }\end{array}$ \\
\hline $\begin{array}{l}\text { kWh } \\
\text { Potential Annual Energy Value } \\
(\$ 0.07 / \mathrm{kWh})\end{array}$ & 15,600 & 20,500 \\
\hline $\begin{array}{l}\text { Energy Present Value }(\$ 0.07 / \mathrm{kWh}) \text { for } \\
20 \text { years at 5 percent interest }\end{array}$ & $\$ 1,092$ & $\$ 1,435$ \\
\hline \multicolumn{1}{|c|}{ Estimated Annual Demand } & $\$ 13,609$ & \\
\hline kWh & $\begin{array}{l}\text { Estimate from } \\
\text { Motor Ratings }\end{array}$ & $\begin{array}{l}\text { Estimate from Utility } \\
\text { Meter Readings }\end{array}$ \\
\hline $\begin{array}{l}\text { Potential Annual Energy Value } \\
\text { Present Value }(\$ 0.07 / \mathrm{kWh}) \text { for 20 years } \\
\text { at 5 percent interest }\end{array}$ & 49,000 & 33,000 \\
\hline
\end{tabular}

Exhibit 2. Estimated annual energy values

tem. The potential present value energy cost savings would be between $\$ 29,000$ and $\$ 43,000$ for 20 years at a 5 percent interest rate.

- Inter-tied with an existing utility energy supply - This would operate the system when there were insufficient wind resources. The potential present value energy cost savings would be between $\$ 14,000$ and $\$ 18,000$ for 20 years at a 5 percent interest rate.

The cost of an independent $10 \mathrm{~kW}$ wind turbine system is approximately $\$ 45,000$, including installation. This cost appears to be very competitive given the power savings estimated above. The wind turbine costs may be more competitive for rural sites where the installation of utility lines to a GCW may range from $\$ 5,000$ to $\$ 10,000$.

The cost analysis appears less attractive for the grid inter-tie system, considering the wind turbine system estimated installed cost of $\$ 35,000$.

The wind turbine project at the former NOP site was originally scoped for an installation independent of utility energy connections at a GCW system designed to be energy-efficient. However, administrative delays in constructing new GCW systems resulted in the installation of a Bergey Windpower Company $10 \mathrm{~kW}$ Excel S Gridtek 10 system on a 100-foot guyed lattice tower for connection to GCW-1. The system is a grid inter-tie system, which means that energy is supplied by the local utility company as well as the wind turbine system. In the event that the wind turbine generates more energy than required by the GCW, the excess energy is transmitted back to the utility grid. Typically, the GCW is operated using a combination of utility and wind turbine energy, but the system is operated only by utility power during periods of low wind. In the event that there is an outage of utility power, the wind turbine system is automatically taken off-line as required by utility company regulations. Therefore, the wind turbine is a supplement to the utility system as opposed to being a replacement during blackout conditions. 
. . electrical demands such as system heating and cooling apparently contribute to significant energy costs.
The wind turbine tower was erected in December 2003, and the system was put into service in January 2004 (Exhibit 3). Exhibit 4 provides details of the electronic monitoring system used to collect power generation and power consumption data. It is important to note that the centrifugal pump, which returns water from the air stripper sump to the recharge screen in the well, is not monitored. It is also assumed that the period of operation of this pump is equal to the period of operation of the submersible pump and the air stripper blower, and that the power demand is equivalent to the motor rating, which is $1 \mathrm{hp}$.

Water samples are collected before and after the air stripper on a monthly basis to estimate the mass of TCE removed from the groundwater.

\section{HISTORICAL PERFORMANCE}

Utility billing records were reviewed to develop Exhibit 5, which shows the quantity of energy purchased for the GCW. Operational records provided the treated groundwater data. Exhibit 6 summarizes the monthly energy purchases. Inspection of the data suggests that the quantity of energy purchased is not closely correlated to the quantity of water treated by the system. For example, the second highest quantity of energy was purchased in February 2003 when the treatment system was inoperable. Therefore, electrical demands such as system heating and cooling apparently contribute to significant energy costs. Exhibit 7 shows the energy purchased versus the water treated. The bestfit line through the origin shows a relatively poor correlation between energy purchase and water treated with an $\mathrm{R}^{2}$ value of 0.29 .

Exhibit 8 shows the energy cost for the system. The unit cost for energy ranged from $\$ 0.06 / \mathrm{kWh}$ to $\$ 0.08 / \mathrm{kWh}$, and service charges were not included in the costs shown on the exhibit. Again, there is poor correlation between energy costs and the quantity of groundwater treated.

Exhibit 9 presents the history of the system flowrate and percentage of system operation time. During the first two years, the system operated 65 to 100 percent of the time on a monthly basis. Operational records indicate that a common reason for system shutdown was related to irregular power supply events associated with the energy purchased from the local utility. Other causes of shutdowns included declining well yields, recharge pump failures, system imbalances, and other events. The system operated at approximately $50 \mathrm{gpm}$ for two years before there was an indication that well efficiency was declining. In November 2002, the system was temporarily taken out of service so that the rehabilitation of the well-extraction screen could be evaluated. The system was put back on line in December 2003 after the rehabilitation of both the extraction and recharge screens, but the original yield could not be restored, and the yield began to decline almost immediately.

Exhibit 10 summarizes the estimated mass of TCE removed by the GCW system. Inspection of the graph shows that there is a wide range of removal rates from less than $2 \mathrm{mg} / \mathrm{kWh}$ to almost $16 \mathrm{mg} / \mathrm{kWh}$. This wide range of removal rates is the result of varying influent concentrations entering the GCW and the widely variable energy consumption rates.

The overall conclusion drawn from the historical data is that there is little correlation between the quantity of energy purchased and the mass of contaminant removed from the aquifer. Furthermore, the GCW was designed to operate continuously, and the data indicate that the system typically operates between 65 and 100 percent of the time. 


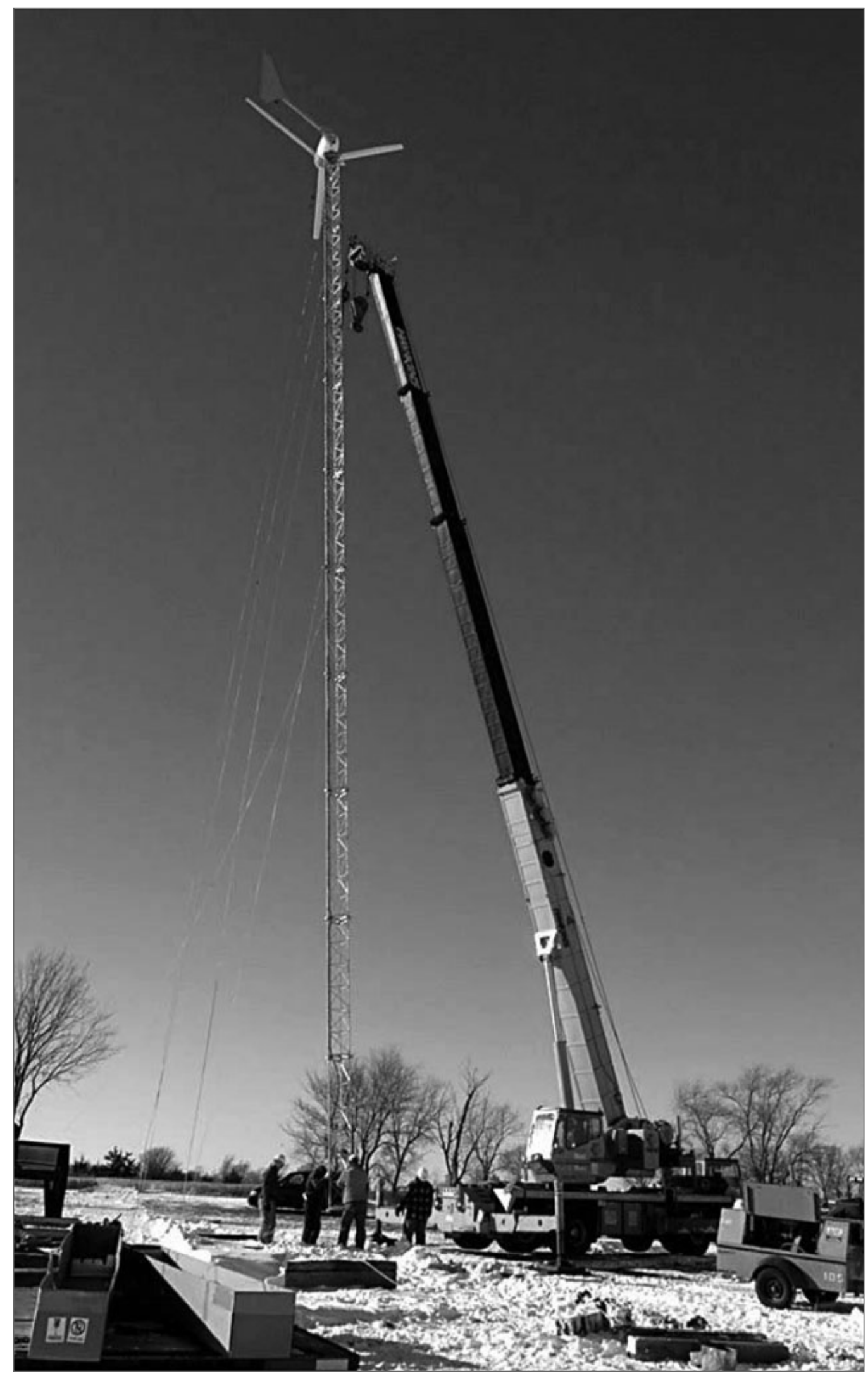

Exhibit 3. Erection of the wind turbine in December 2003 


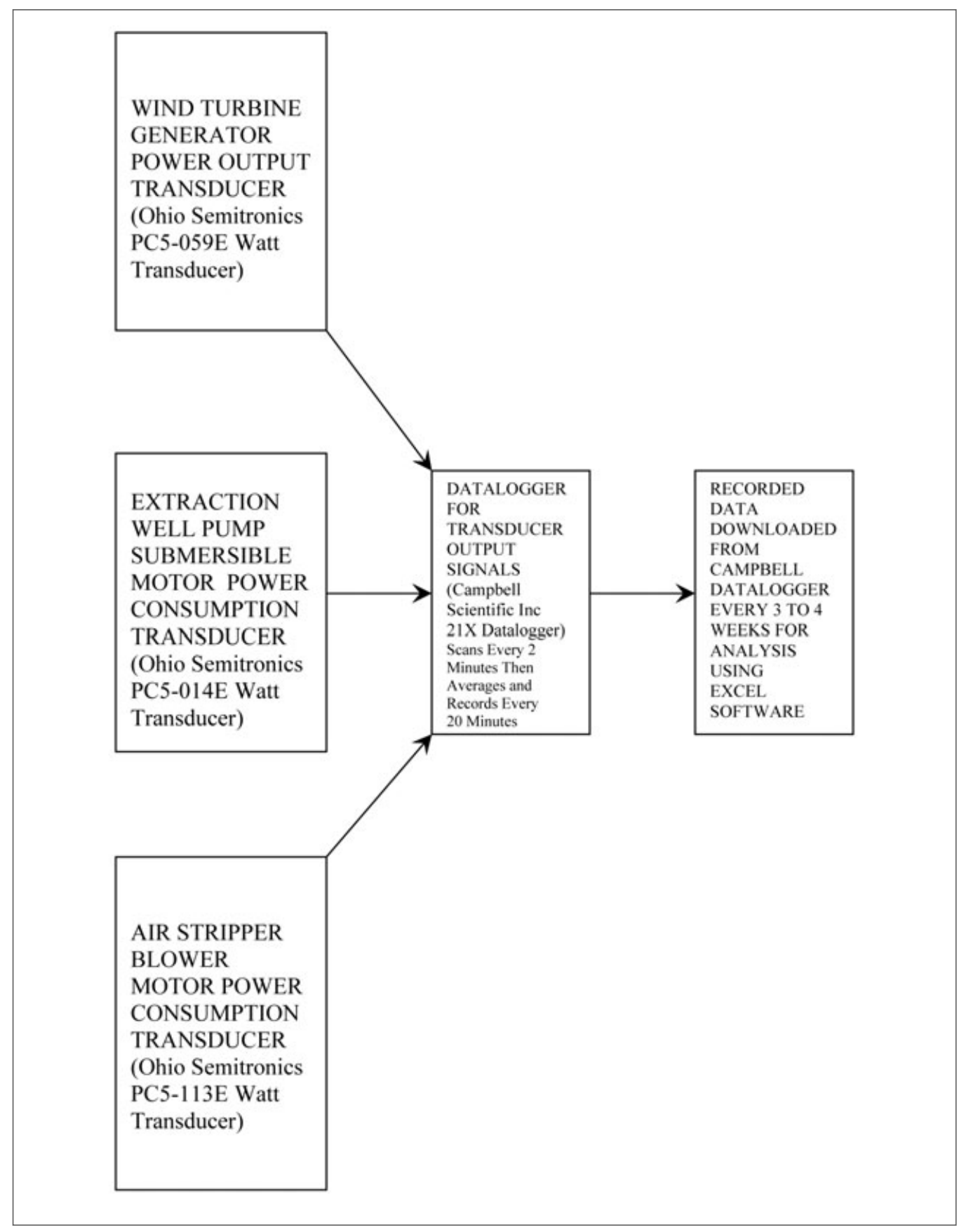

Exhibit 4. Power generation and consumption monitoring schematic

\section{WIND TURBINE PERFORMANCE}

Data regarding power generation by the wind turbine system and power consumption by the GCW treatment components have been collected continuously since January 21, 2004. Exhibit 11 shows the energy generated and energy consumed in March 2004. The energy curves for the other months are relatively similar. Exhibit 12 summarizes the energy data as well as the contaminant mass removal data for the time period beginning with the initiation of wind turbine service. 


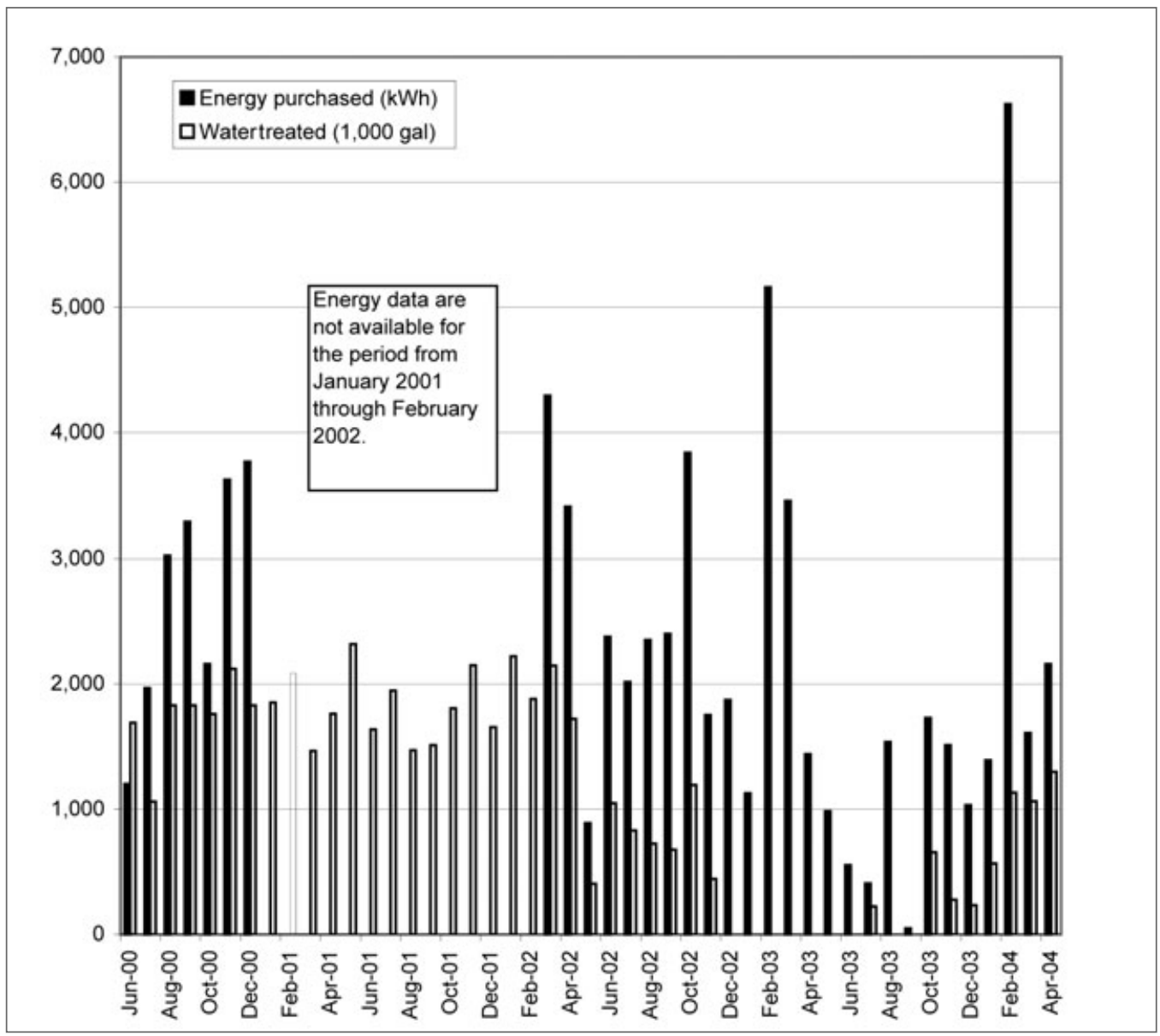

Exhibit 5. Historic purchase of energy and volume of water treated

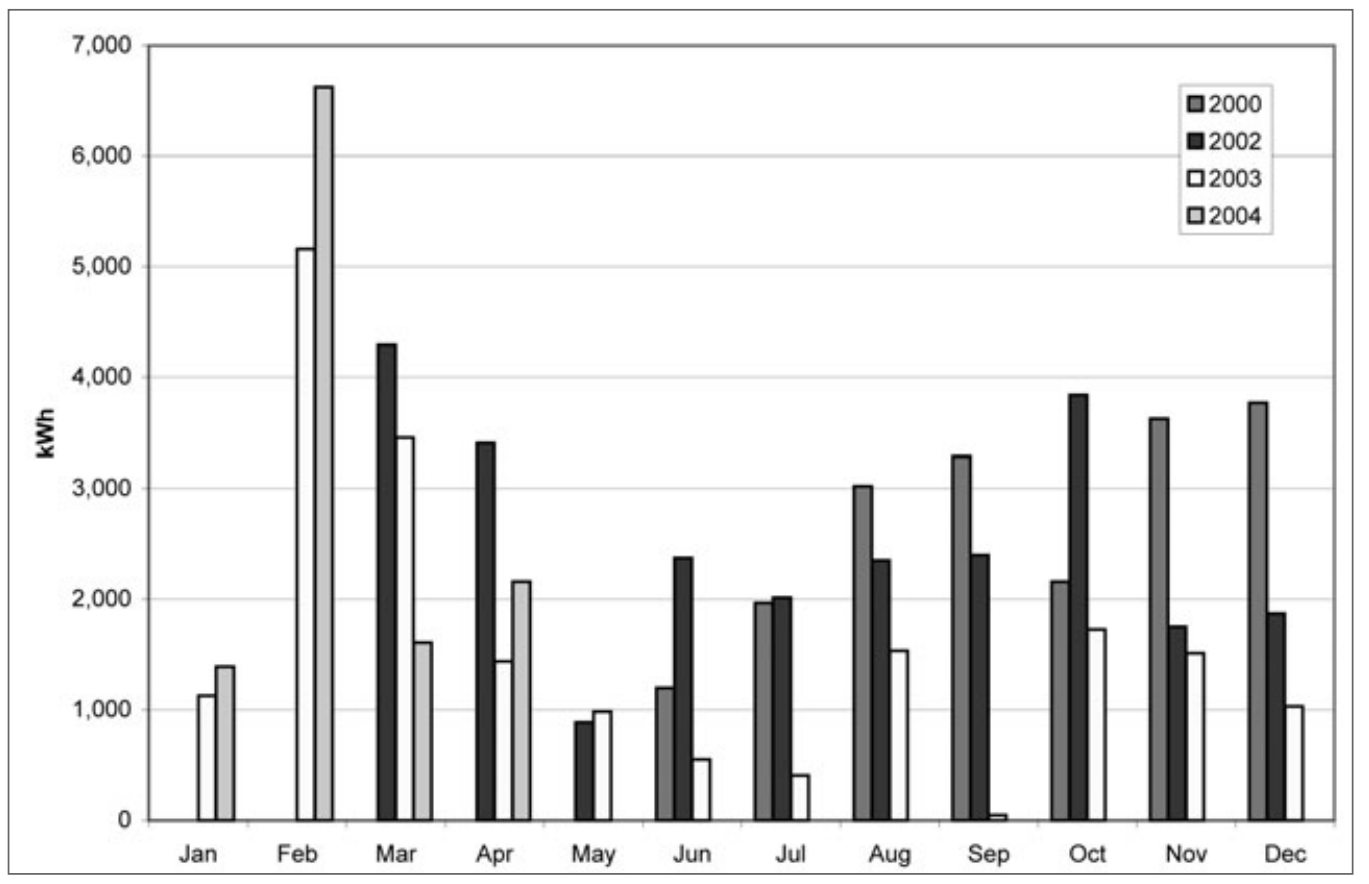

Exhibit 6. Monthly summary of purchased energy 


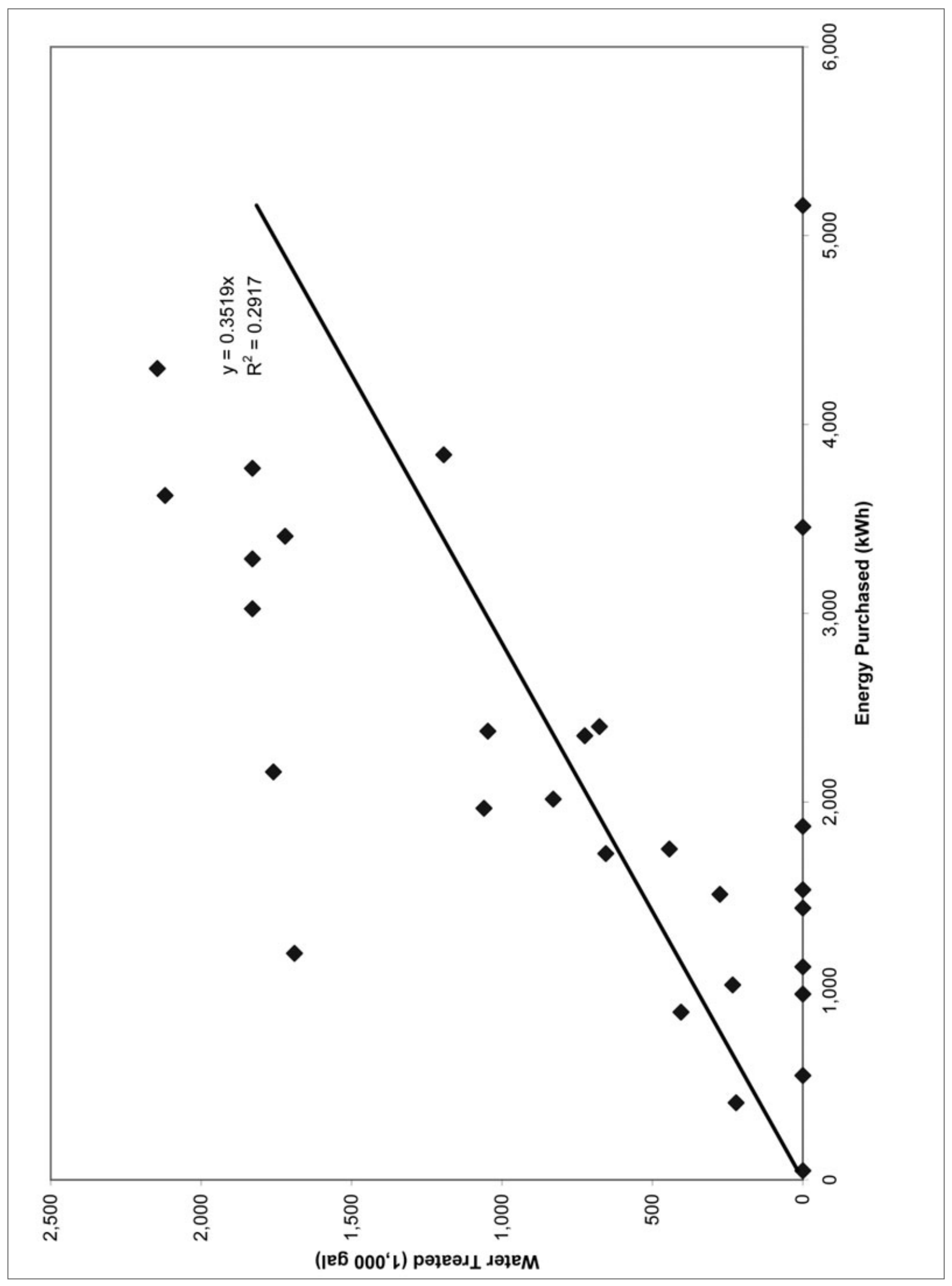

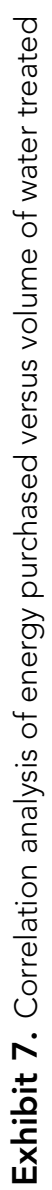




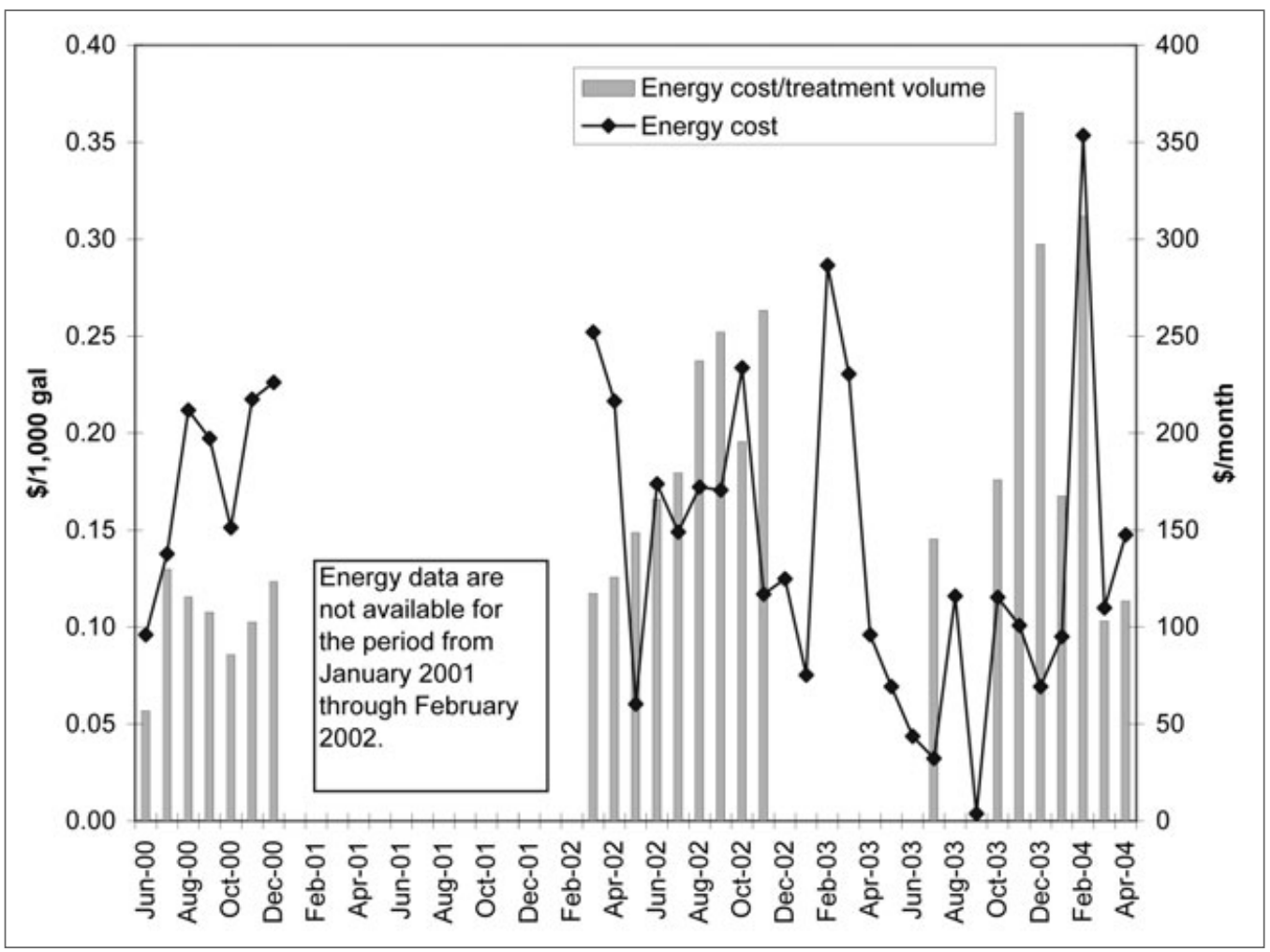

Exhibit 8. System energy costs

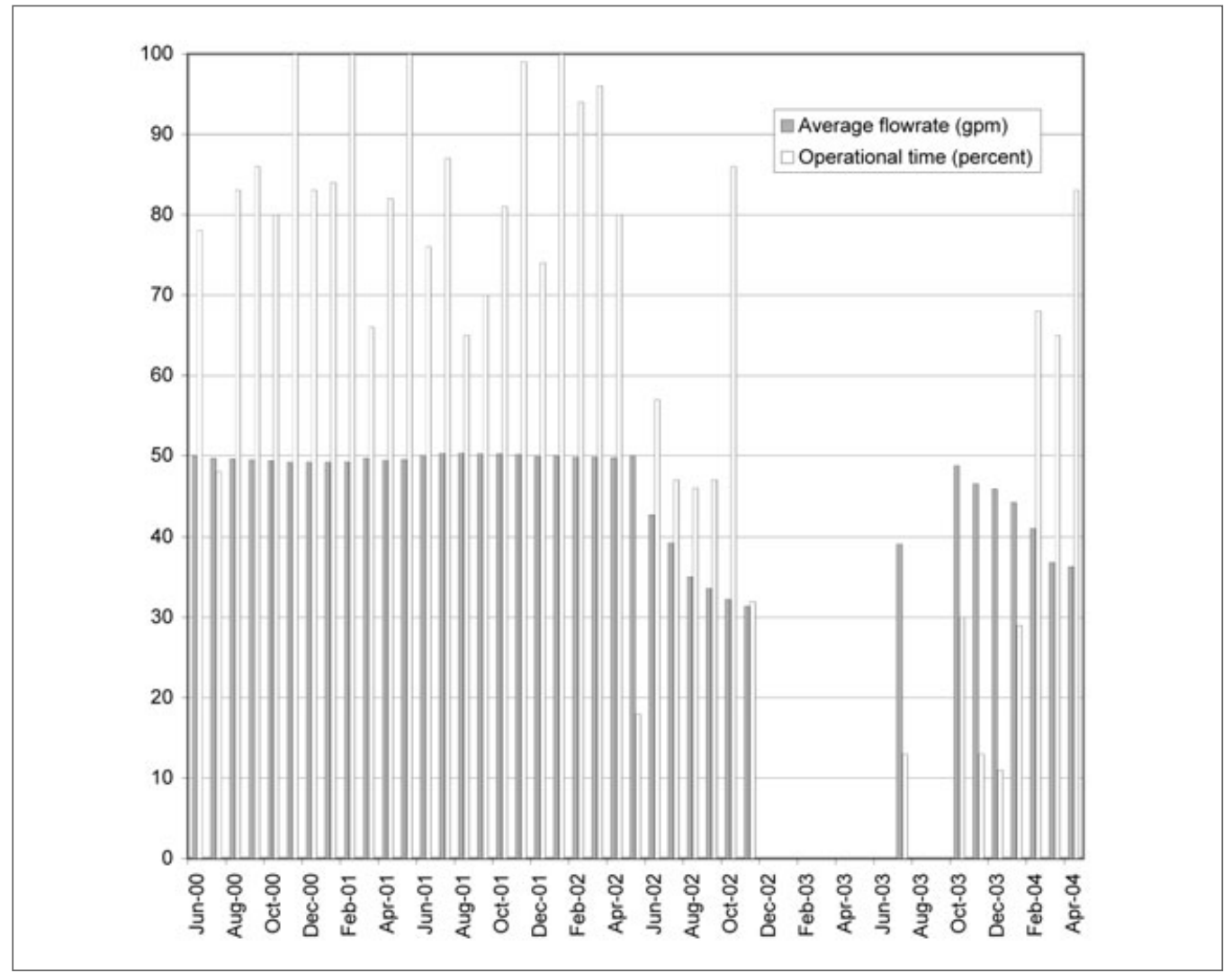

Exhibit 9. System operational time 


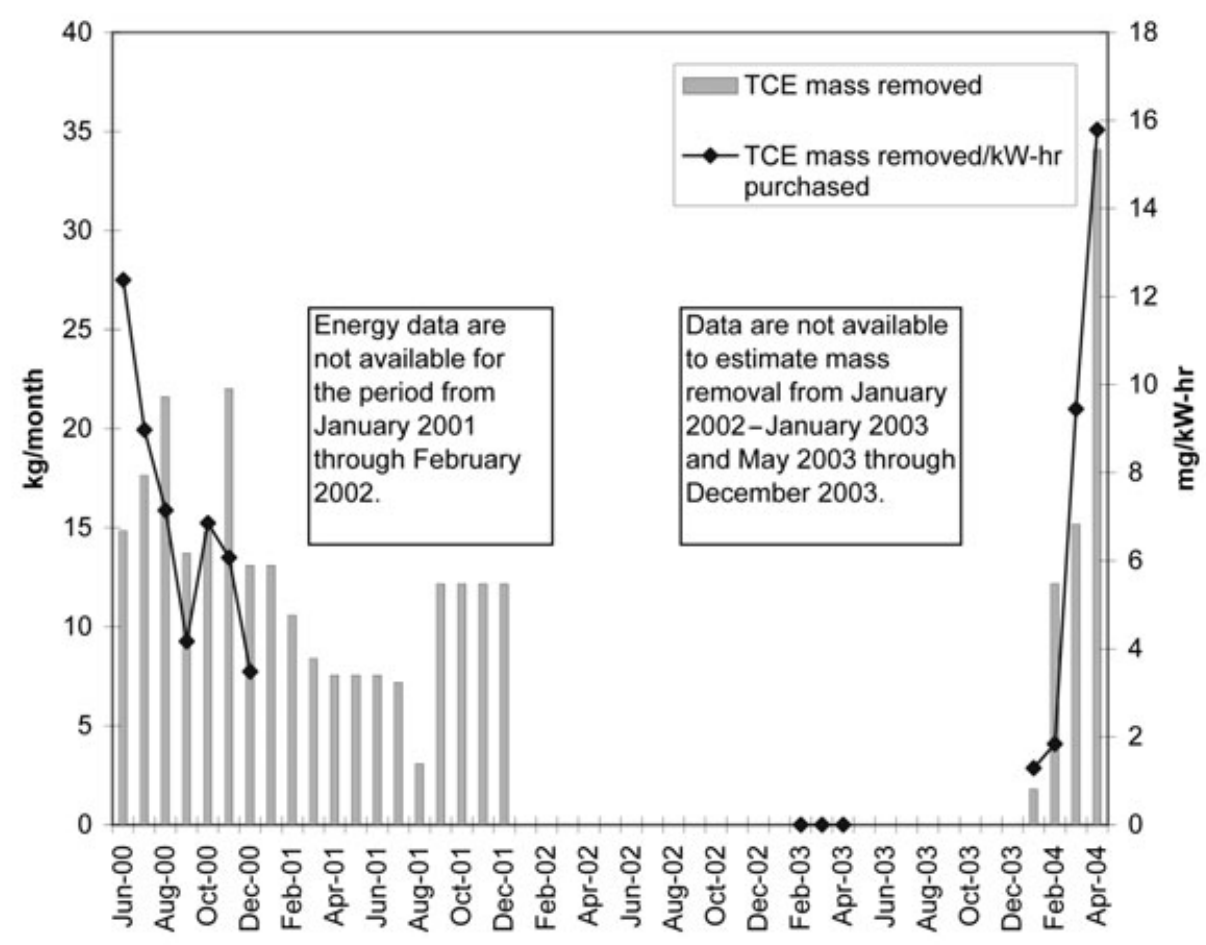

Exhibit 10. Estimated TCE mass removal

The average monthly energy production can be estimated from the annual value estimated from the modified Weibull model value of 1,300 kWh (Exhibit 2). This is almost double the average monthly value presented in Exhibit 12 for the first four months of wind turbine operation. Although the actual production is significantly lower than the design estimate, the estimated energy consumption is much less than that estimated in Exhibit 2. In terms of the overall energy balance, the preliminary results indicate that the wind turbine energy production exceeds the treatment system demand.

The Exhibit 12 summary indicates that the system is removing approximately $21 \mathrm{mg}$ of TCE per kWh of energy generated by the wind turbine. Examination of the flowrate data presented in Exhibit 9 shows that the average flowrate of the system has been declining since October 2003. Therefore, if the mass of TCE is proportional to the flowrate, the current operational status of the system at flowrates less than $50 \mathrm{gpm}$ depresses the rate of TCE mass removal per unit of energy generated by the wind turbine.

Exhibit 11 shows that energy production is a highly variable, random event, while the energy consumption is relatively constant. Although the treatment system operational period is a random variable because it cannot be predicted a priori, the magnitude of the treatment power demand is relatively constant at $4.7 \mathrm{~kW}$. The Exhibit 12 energy balance indicates that the wind turbine generates more energy than that required by the treatment system during the preliminary months of the project.

However, timing of the energy delivery does not match the energy demand. For the grid inter-tie system, other electrical processes for the GCW system either use the excess energy or, if the supply exceeds the total GCW demand, the excess enters the utility grid. Net metering refers to the practice of giving utility customers who deliver 


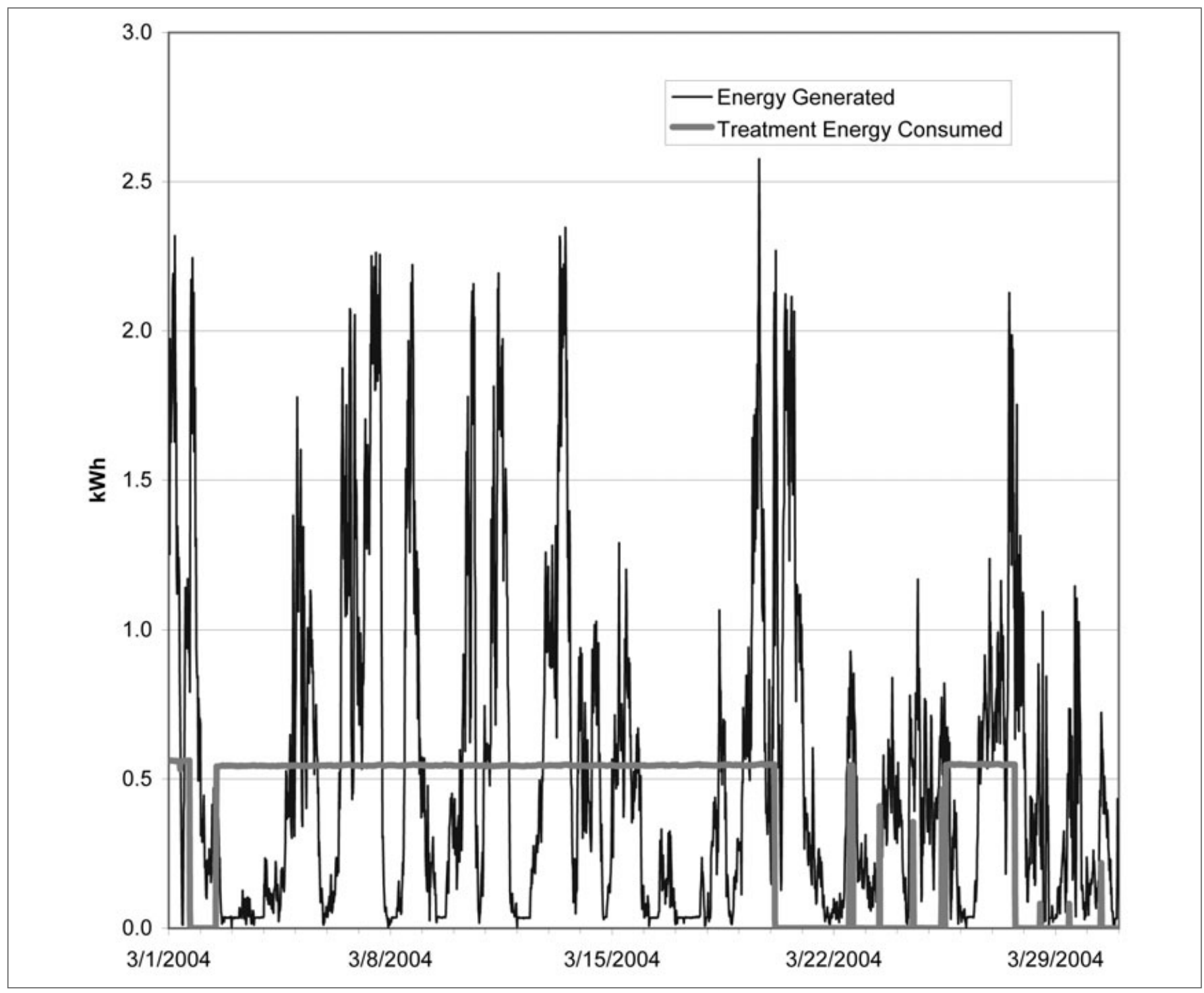

Exhibit 11. Energy curves for March 2004

generated power in excess of demand to the utility compensation for that power. This practice makes the grid inter-tie systems more economically attractive. Unfortunately, net metering is not practiced in Nebraska. Given an estimated price of $\$ 0.07 / \mathrm{kWh}$, the average monthly value of the wind-generated energy is $\$ 57 /$ month. In theory, this should represent a cost savings for the system. However, a reduction in energy consumption is not obvious from an inspection of the data presented in Exhibit 5. In fact, more than 6,500 kWh of electricity were purchased during February 2003, which is the maximum monthly use given the available data. The wind turbine system contributed an additional $770 \mathrm{kWh}$ during the same period.

The GCW continues to remove contaminant mass from the aquifer without removing water from the aquifer. Estimated monthly mass removal quantities of $10 \mathrm{~kg}$ are not unusual, and almost $21 \mathrm{mg}$ of TCE are being removed with each kWh of energy generated by the wind turbine system. 


\begin{tabular}{|c|c|c|c|c|c|}
\hline Month & $\begin{array}{l}\text { Energy Generated } \\
\text { (kWh) } \\
\text { (a) }\end{array}$ & \begin{tabular}{|} 
Energy Consumed \\
by Treatment \\
System \\
(kWh) \\
(b)
\end{tabular} & $\begin{array}{c}\text { Difference } \\
\text { kWh } \\
\text { (a)-(b) }\end{array}$ & $\begin{array}{l}\text { Operational } \\
\text { Time }\end{array}$ & $\begin{array}{c}\text { TCE } \\
\text { Removed } \\
\text { per kWh } \\
\text { Generated } \\
\text { (mg/kWh) }\end{array}$ \\
\hline Jan-04 & 209 & 279 & -70 & $75 \%$ & 8.6 \\
\hline Feb-04 & 771 & 824 & -53 & $72 \%$ & 15.8 \\
\hline Mar-04 & 1,148 & 814 & 335 & $67 \%$ & 13.2 \\
\hline Apr-04 & 935 & 917 & 17 & $78 \%$ & 36.5 \\
\hline May-04 & 1,024 & 1,001 & 23 & $82 \%$ & - \\
\hline Total & 4,087 & 3,835 & 252 & - & - \\
\hline $\begin{array}{l}\text { Monthly } \\
\text { Average }\end{array}$ & 817 & 767 & 50 & $75 \%$ & 20.7 \\
\hline \multicolumn{6}{|c|}{$\begin{array}{l}\text { Notes: } \\
\text { 1. System monitoring was initiated on January } 21,2004 \text {. } \\
\text { 2. Data were not available at submittal time to estimate the mass of TCE removed in } \\
\text { May } 2004 \text {. }\end{array}$} \\
\hline
\end{tabular}

Exhibit 12. Wind turbine performance summary

\section{CONCLUSIONS AND RECOMMENDATIONS}

To the best of our knowledge, this is the first application of a wind turbine to power a groundwater remediation system. The system was well received by the public, and efforts are underway to provide an outreach program with local schoolchildren. The wind turbine has no known negative impact on wildlife, the environment, or land use. The historical data collected for the system indicate that there is a poor correlation between the quantity of energy purchased and the quantity of water treated at the GCW system. The subject GCW system was constructed as a prototype for the collection of data to be used during the design of subsequent systems. This subject system may be relatively inefficient in terms of energy used to heat and cool the treatment system components. Although the wind system generates sufficient energy to satisfy the needs of the treatment system, including the submersible well pump, the wind energy supply falls far short of matching the quantity of energy purchased for the system. It is concluded that the cost efficiency of future systems would greatly benefit if one of the bases of design was energy efficiency. Furthermore, the preliminary results indicate that it may be possible to operate the GCW system using solely wind power if the only energy demands were those required for circulating and treating groundwater.

The data indicate that the GCW, which was designed for "continuous" operation, operates, on average, approximately 75 percent of the time. It may be concluded that this time period would be appropriate for the design of an off-grid renewable energy system. That is, it would only be necessary to specify energy storage capabilities, which would result in system operation 75 percent of the time instead of 100 percent of the time.

The preliminary data collected from this study also encourage the development of a remedial system that uses wind energy without storage. A significant quantity of groundwater could be pumped if a variable frequency drive pump matched to the wind turbine was employed at the study site or a site with similar or greater wind resources. 


\section{ACKNOWLEDGMENTS}

The wind turbine project was funded by a grant from the U.S. Environmental Protection Agency Office of Solid Waste and Emergency Response Innovative Work Groups program. The U.S. Army Corps of Engineers, Kansas City District, their contractors, the University of Missouri-Rolla, Bergey Windpower Company, Inc., and Ohio Semitronics, Inc. provided additional support.

\section{REFERENCES}

Elliott, D. L., Holladay, C. G., Barchet, W. R., Foote, H. P., \& Sandusky, W. F. (1986). Wind energy resource atlas of the United States. DOE/CH 10093-4. Golden, CO: U.S. Department of Energy Pacific Northwest Laboratory.

Elmore, A. C., \& DeAngelis, L. (2004). Modeling a groundwater circulation well alternative. Ground Water Monitoring and Remediation, 24(1), 66-73.

Elmore, A. C., \& Graff, T. (2001). A case study of the beneficial reuse of treated groundwater. Remediation, 11(3), 49-62.

Elmore, A. C., \& Graff, T. (2002). Best available treatment technologies applied to groundwater circulation wells. Remediation, 12(3), 63-80.

Elmore, A. C., \& Hellman, J. B. (2001). Model-predicted groundwater circulation well performance. American Society of Civil Engineers Practice Periodical of Hazardous, Toxic, and Radioactive Waste Management, 5(4), 203-210.

Gipe, P. (1995). Wind energy comes of age. New York: Wiley.

Global Energy Concepts, Inc. (GEC). (1999). Nebraska wind energy site data study, final report. Report prepared for Nebraska Power Association. For copy, write to NPA, c/o Dave Ried, Omaha Public Power District, 444 South 16th St. Mall, 4E/EP 1, Omaha, NE, 68102-2247.

United States Environmental Protection Agency (US EPA). (1990). NPL site narrative for Nebraska Ordnance Plant (former). Retrieved September 9, 2003, from http://www.epa.gov/superfund/sites/npl/nar1262.htm

Andrew Curtis Elmore is an assistant professor of geological engineering at the University of Missouri-Rolla. His areas of expertise include design and analysis of groundwater circulation wells, sustainable groundwater design, and characterization of water supply sources in Guatemala.

Ron Gallagher is a PhD student in the University of Missouri-Rolla geological engineering program, where he is studying the application of renewable energy to groundwater remediation systems.

K. David Drake is a remediation project manager in the Federal Facilities Section of Region 7, U.S. Environmental Protection Agency. He provides technical leadership for the remediation of Superfund sites throughout Region 7. 